\title{
POSISI DAN STATEGI PENDIDIKAN ISLAM DI ERAGLOBALISASI
}

\author{
Mahmudi \\ Universitas Nahdlatul Ulama Lampung \\ Mahmudi.m.pd.i@gmail.com
}

\begin{abstract}
Opportunities and challenges of globalization require superior and competitive human resources, which need to be responded positively by Islamic education. These opportunities need to be fulfilled by utilizing all the positive potentials of globalization, spreading Islamic values to the world as an effort to save humanity from the scularization virus that ignores the spiritual dimension in humans. In addition, Islamic education must develop a spiritual-based education that is fully supported by teachers, students and educational organizations that fully support prophetic transformational leadership, therefore the teaching and learning strategy can be developed in accordance with the demands of the times.
\end{abstract}

Keywords: globalization, Islamic education, position, strategy

\begin{abstract}
ABSTRAK
Peluang dan tantangan globalisasi membutuhkan sumber daya manusia yang unggul dan kompetitif, yang perlu direspon secara positif oleh pendidikan Islam. Peluang-peluang ini perlu dipenuhi dengan memanfaatkan semua potensi positif globalisasi, menyebarkan nilainilai Islam ke dunia sebagai upaya menyelamatkan manusia dari virus skularisasi yang mengabaikan dimensi spiritual dalam diri manusia. Selain itu, pendidikan Islam harus mengembangkan pendidikan berbasis spiritual yang didukung penuh oleh para guru, pelajar, dan organisasi pendidikan yang sepenuhnya mendukung kepemimpinan transformasional kenabian, oleh karena itu starategi pengajaran dan pembelajaran bisa dikemangakan sesuai dengan tuntutan zaman.
\end{abstract}

Kata Kunci: globalisasi, pendidikan Islam, Posisi, Strategi 


\section{Mahmudi}

\section{A. PENDAHULUAN}

Era globalisasi memberi dampak yang cukup luas dalam berbagai aspek kehidupan, termasuk tuntutan kualitas dalam penyelenggaraan pendidikan. Pada era ini, setiap bidang dalam kehidupan modern menuntut sumber daya manusia berkualitas yang memiliki kemampuan tinggi dan handal, sehingga persaingan terutama yang terkait dengan kualitas sumber daya manusia sangat ketat. Untuk memenuhi tuntutan ini perbaikan dan pengembangan sistem penyelenggaraan pendidikan pada setiap satuan secara berkesinambungan perlu dilakukan sejalan dengan dinamika perkembangan sains dan teknologi serta dinamika perubahan mansyarakat itu sendiri (Mohammad, 2009).

Globalisasi telah menempatkan mutu sumber daya manusia sebagai hal yang sangat penting dalam proses pembangunan. Dalam konteks peningkatan mutu sumber daya manusia tersebut, pendidikan merupakan strategi utama. Namun krisis ekonomi mulai tahun 1997 telah melemahkan posisi pemerintah sebagai pemain utama di sektor ini. Disamping itu, krisis juga telah melemahkan kemampuan rumah tangga untuk mengirimkan putra-putrinya ke sekolah. Diperlukan cara untuk meningkatkan efisiensi dan efektifitas sistem alokasi pendanaan pendidikan, yang pada gilirannya akan terkait dengan proses desentralisasi kewenangan dari pemerintahan pusat ke pemerintahan daerah. Namun sampai saat ini studi mengenai pembiayaan pendidikan masih sangat kurang di Indonesia. Hal ini sangat disayangkan, terutama mengingat pentingnya aspek pembiayaan ini dalam upaya peningkatan mutu pendidikan (Mohammad, 2009).

Pendidikan yang berkualitas dapat menghasilkaan sumber daya manusia yang berkualitas yang akan memberi kontribusi kepada keberhasilan pembangunan. Para pemakai lulusan, seperti dunia bisnis dan industri atau bahkan pada umumnya masyarakat, juga mengharapkan agar pendidikan berkualitas sehingga tenaga kerja atau sumber daya manusia yang direkrut benar-benar produktif (Fasli Jalal, 2001).

Dalam Renstra Diknas, Visi pendidikan nasional sampai dengan tahun 2025 adalah menciptakan SDM dan lembaga pendidikan yang punya daya saing ragional dan internasional. Untuk mengantisipasi pasar bebas ASEAN mulai 2015 dan pasar bebas dunia berlaku tahun 2020. Pada tahun 2015-2020 difokuskan pada kualitas pendidikan yang memiliki daya saing regioanl pada tingkat ASEAN. Standar mutu periode ini diharapkan relevan dengan pasar ASEAN. Program kerja pendidikan nasional didasarkan pada kebutuhan pasar regional, diantarnya melalui standarisasi, penjaminan mutu, akreditasi satuan pendidikan. Sasarannya adalah beroperasinya 
sistem layanan dengan standar ASEAN, citra depdikbut, kerjasama ASEAN.

Pada tahun 2025 dicanangkan pencapaian nilai kompetetif secara internasional. Program pendidikan diarahkan pada skala mutu internasional. Oleh karena itu, depdikbut harus mempunyai layanan standar internasional, citra yang kuat dan kerjasama internasional. Tujuannya adalah terciptanya kondisi yang diharapkan (ex cepted condition), berdasarkan kondisi yang ada (existing condition), dan tercipta (developed condition) berdasarkan proses perencanaan, implementasi, dan evaluasi yang berkesinambungan (RSDPN, 2005).

Arus globalisasi tersebut membawa berkah berupa peluang bagi pengembangan pendidikan Islam. Pada sisi lain, terdapat tantangan berupa ancaman yang bisa memberangus pendidikan Islam yang notabeni belum begitu banyak yang unggul dalam melahirkan SDM yang handal. Untuk menjawab permasalahan eksternal tersebut, yang berupa tantangan dan peluang yang dibawa oleh globalisasi, diperluakn langkah yang harus dilakukan secara sistematis dan masif serta terus menerus. Oleh karena itu, apa strateginya untuk menjawab permasalahan di atas?

\section{B. HASIL KAJIAN DAN PEMBAHASAN}

\section{Arus Globalisasi}

Pengertian Globalisasi cukup beragam ada yang mengartikan bahwa globalisasi merupakan agenda ekonomi global. Yang ditandai dengan adanya arus perdagangan bebas antar bangsa. Ada lima pengertian globalisasi menurut J.A. Scholter (2002) seperti yang dilansir oleh Rudi Hermawan. Globalisasi sebagai internasionalisasi, liberalisasi, universalisasi, modernisasi, dan penghapusasn batas-batasteritorial.

Globalisasi sebagai internasionalisasi adalah gambaran pertumbuhan dalam pertukaran dan interdependensi internasionalisasi dengan sistem yang melalui proses dan kesepakatan internasional. Globalisasi sebagai liberalisasi adalah sebuah proses penghapusan hambatanhambatan yang dibuat pemerintah terhadap mobilitas antar negara. Globalisasi sebagai universalisasi adalah proses mendunia dan globalisasi merupakan proses penyebaran berbagai objek dan pengalaman kepada seluruh penjuru dunia.

Globalisasi sebagai modernisasi adalah sebuah dinamika, dimana struktur- struktur sosial modernisasi (kapitalisme, rasionalisme, industrialisme, birokratisme, dsb) disebarkan ke seluruh dunia, yang dalam prosesnya cenderung merusak budaya setempat yang telah mapan 


\section{Mahmudi}

serta merampas hak identitas rakyat setempat. Globalisasi sebagai penghapus batas-batas teritotial adalah rekonfigurasi geografis sehingga ruang sosial tidak lagi semata-mata dipetakan dengan kawasan teritorial, jarak teritorial, dan batas-batas teritorial. Lebih lanjut Hermawan mengutip pendapat Sam M.Chan dan Tuti. T.Sam yang menyatakan bahwa globalisasi merupakan konsep pasar bebas persaingan sempurna (the perfect market) yang merupakan kondisi yang memungkinkan seluruh pemain dalam pasar persaingan bebas dapat keluar dan masuk pasar sesuai dengan pertimbangan rasionalnya masing-masing.

Secara historis, menurut (Sahlins, 1994), sebagaimana kutipan (Bachtiar Alam, 1997) bahwa proses globalisasi bukanlah suatu yang baru mulai akhir-akhir ini, yang disebabkan oleh lonjakan perkembangan sistem komunikasi, tapi sejak masa lalu setiap masyarakat di muka bumi ini merupakan suatu masyarakat global.

Banyak peluang yang dapat dipetik dari globalisasi. Pemanfaatan globalisasi harus diikuti oleh upaya untuk mengatasi dampak negatif dari globalisasi secara sadar dan terarah. Dalam kaitan ini orang berbicara mengenai sustainable globalization, yaitu globalisasi yang berkelanjutan (Hadi Soesanto, 2004). Liberalisme ekonomi berarti jaminan adanya kebebasan bagi semua insan ekonomi untuk menentukan sendiri apa yang akan dikonsumsi, apa yang akan diproduksi, bagaimana memproduksinya, dan untuk memperdagangkannya.

Dengan demikian, dalam globalisasi ada yang diuntungkan dan ada yang dirugikan, ada yang menang dan ada yang kalah Hadi Soesanto. Problemnya adalah terjadi persaingan yang tidak sehat, karena terjadi persaingan bebas. Dan tidak etis karena membiarkan orang lain merugi dan kalah, yang akhirnya menjadi limbah pembangunan. Pertanyaannya siapa yang bertanggungjawab untuk itu. Oleh karena itu, pendidikan Islam harus mengambil peran di era globalisasi.Yaitu menyiapkan sumber daya manusia yang unggul berbasis profetik guna menangkal bawaan negatif globalisasi tersebut.

\section{Pekerjaan Rumah Pendidikan Islam}

\section{Kekuatan Pendidikan Islam}

Kekuatan yang dimiliki oleh pendidikan Islam adalah keberadaannya di panggung sejarah sepanjang sejarah peradaban Islam, dari zaman awal Islam, abad pertengahan sampai era modern ini. Disamping itu, fungsi profetis pendidikan Islam yang tiada duanya di dunia. Fungsi profetis ini merupakan pelembagaan dan penyebaran misi/risalah Islamiyah yang 
diwariskan oleh Nabi Muhammad.

Kekuatan lainnya adalah fungsi educatifnya, yaitu lembaga pencatak insan kamil yang berwawasan global. Umat Islam ikut membantu pembangunan sumber daya manusia Indonesia melalui pendirian Pendidikan Islam. Disamping karena tanggungjawab keagamaan, keberadaan pendidikan Islam juga dimaksudkan sebagai wujud dari rasa tanggung- jawab sosial kemasyarakatan dan kebangsaan. Walaupun secara struktural, kewajiban mencerdaskan bangsa adalah tugas negara dengan cara memberikan pendidikan terhadap warga negaranya sebagaimana yang diatur dalan Undang Undang.

Nilai pendidikan sudah bersemayam dalam sanubari umat, karena diyakini bahwa pendidikan sebagai bentuk investasi sumber daya manusia yang dalam teori human capital dianggap sebagai capital goods yang dapat menentukan upaya pencapaian manfaat dan produktivitas dalam bentuk kapital lainnya (Mohammad, 2009).

\section{Kelemahan Pendidikan Islam}

Membaca hasil penelitian internasional tentang kualitas pendidikan di Indonesia tentu membuat kita miris. Mayoritas hasil penelitian tersebut menempatkan Indonesia pada posisi yang menyedihkan. Penelitian Program fot International Student Assessment (PISA) yang terbaru tentang kemampuan siswa pada matematika, membaca, dan sains menempatkan Indonesia pada posisi 64 dari 65 negara. Penelitian The Learning Curve (2014) tentang skill kognitif dan pencapaian akademis menempatkan Indonesia pada posisi paling buncit, yaitu posisi 40 dari 40 negara. Kemudian, hasil penelitian dari United Nations Development Program (UNDP) tentang Human Development Index yang terbaru (2014) menempatkan Indonesia berada pada posisi ke-108 dari 187 negara. Hasil penelitian internasional tersebut menunjukkan kualitas pendidikan di Indonesia belum mampu bersaing dengan negara-negara lain, bahkan dibandingkan dengan negara-negara ASEAN sekalipun (Nanang, 2014).

Dalam konteks mikro pendidikan, bangsa Indonesia harus melakukan langkah-langkah yang solutif integratif untuk meningkatkan kualitas pendidikannya. Janganlah isu pergantian kurikulum ini menguras energi secara berlebihan. Bahasa sederhananya, ayo segera move on dari isu pergantian Kurikulum 2013. Berbicara tentang peningkatan kualitas pendidikan, laporan dari Education International Analysis (EIA) "Education For All by 


\section{Mahmudi}

2015" (2008) mengungkapkan, paling tidak ada tiga tantangan utama dalam kaitannya dengan kualitas pendidikan.

1. Pertama, hasil belajar harus dipantau.

2. Kedua, peningkatan lingkungan belajar.

3. Ketiga, memberi perhatian yang lebih baik pada guru, dan yang ketiga inilah yang utama.

Menurut Budi Santoso (2014), selaku komisioner ombudsman RI, mengatakan bahwa terdapat masalah pendidikan yang harus diperbaiki yaitu: pertama, adalah masalah penerimaan peserta didik baru yang penuh masalah. Kedua, soal ujian nasional (UN) yang kisruh. Ketiga, dana Bantuan Operasional Sekolah (BOS) yang kerap terjadi keterlambatan penyaluran dana BOS dan penyimpanan dana. Keempat, Komite Sekolah yang kurang berpren optimal. Kelima, kekerasan di sekolah. Ketidakjelasan dan ketidaktegasan sanksi terhadap pelaku kekerasan dan lemahnya pengawasan oleh pihak sekolah menjadi penyebab masalah ini tetap ada. Keenam, sertifikasi guru yang dipungli dan tidak lancar. Ketujuh, Kurikulum yang menimbulkan problimatik dan polemeik.

Masalah mendasar lainnya, adalah dunia pendidikan yang meng- agungkan intelektualistik dan cenderung mengabaikan spiritualitas. Zaim Uchrawi (2014) mengatakan bahwa sejak Bapak Filsafat Modern Rene Descartes (1596-1650) mengemukakan ungkapan itu, "berfikir" menjadi begitu penting di dunia. Paradigma analitis logis Cartesian, paham yang didasarkan pada pandangan Descartes, dengan segera menggusur cara pandang holistik Ibnu Sina (980-1037) yang mendominasi global selama enam abad.

Bapak Pendidikan Ki Hajar Dewantara pernah mencoba melawan arus tersebut. Ia mengusung pendekatan holistik ketimuran. Ungkapan ing ngarso sung tulodo, ing madyo mangun karso, tut wuri handayani merupakan produk cara pandang itu. Kalangan pendidikan Indonesia mengapresiasi dan mengutip ucapannya, tapi diam-diam lebih mengadopsi paham Cartesian. Alasannya sederhana. Kognitif, sekali lagi, paling mudah diukur. Selain itu, buku-buku teks Barat tersedia melimpah untuk dijadikan buku teks babon. Tak ada buku teks babon berbasis pemikiran Ki Hajar Dewantara. Pemerintah pun tak tertarik mengembangkannya, sebagaimana para universitas negeri (mantan IKIP) juga tak tertarik pendekatan kualitatif karena dianggap “kurang ilmiah”( Zaim, 2014).

Dengan paradigma seperti itu, pendidikan nasional pun kering dan jauh dari efektif. 
Apalagi dengan administrasi birokrasi yang terlanjur biasa bekerja dengan sistem ad hoc. Belum lagi penurunan kualitas SDM pendidikan setelah putra-putra terbaik bangsa lebih banyak diserap sektor lain. Sebagian besar mereka hanya mampu mengajar. Bukan mendidik. Itu pun secara pas-pasan. Maka, pendidikan nasional pun terus mengajarkan pengetahuan atau "berpikir". Bukan mendidik. Hal yang diharapkan membuat siswa cerdas, tapi membuat hasil sebaliknya. Menurut penilaian program internasional PISA, daya nalar siswa Indonesia termasuk terendah dibanding bangsa lain. Wajar bila Menteri Anies Baswedan menyebut dunia pendidikan Indonesia sudah gawat darurat.

Untuk itu spiritualitas pendidikan diperlukan dengan cara menge- depankan aspek kultural-spiritual dan keteladanan. Pengajar perlu ditransformasi menjadi pendidik. Dengan spiritualitas pendidikan, olah hati menjadi yang pertama. Baru kemudian diikuti dengan olah pikir, olah raga, serta olah rasa dan karsa.

\section{Strategi Pendidikan Islam di Era Globalisasi}

1. Strategi Profetis. Artinya memanfaatkan kekuatan LPI untuk menjawab peluang globalisasi. Nilai profetis dapat menjadi penangkal gersangnya kehidupan modern akibat logis dari paradigma skular sebagai landasan peradabannya. Misi profetis yang ditawarkan oleh Kuntowijoyo adalah humanisasi, liberasi dan transendensi.

2. Strategi Reinventing. Artinya kembali pada hakekat pendidikan Islam, yaitu meletakkan dunia rohaniyah/spiritualitas sebagai landasan pendidikan dimana pendidikan selama ini jauh dari dunia spiritual dan cenderung mereduksi hakikat kemanusian hanya sebagai skrup industrialisasi yang eksploitatif.

3. Perlu dukungan lanjutan berupa guru yang bergairah, organisasi pembelajar, serta dukungan penuh dari kepemimpian pendidikan profetk transformatif.

Tiga hal penting yang perlu diperhatikan terus menerus bila ingin mewujudkan pendidikan bermutu, yaitu:

1. Pertama, pemantauan hasil belajar siswa jangan hanya dilakukan pada akhir masa sekolah atau hanya dilihat dari hasil ujian. Namun, hendaknya dilihat juga dari proses saat pembelajaran berlangsung. Pemantauan juga dilakukan agar tidak terjadi kesenjangan hasil belajar antara murid di perkotaan dan perdesaan, antara murid yang berlatar 


\section{Mahmudi}

belakang sosial ekonomi rendah dan yang tinggi. Pemantauan itu harus diikuti dengan usaha untuk meningkatkan keterlibatan dan keaktifan siswa dalam belajar, juga penggunaan metode mengajar yang menarik.

2 Kedua, peningkatan lingkungan belajar. Akses ke sumber belajar perlu ditingkatkan. Buku-buku teks dan buku penunjang serta media pembelajaran semestinya dimiliki dan mudah diakses oleh guru dan murid. Kenyamanan ruang kelas dan sekolah juga harus diperhatikan. Ruang sekolah yang bocor, ventilasi udara yang tidak baik, kebisingan dan pengap harus diperbaiki. Kemudian pada era modern ini, akses ke teknologi, seperti penggunaan IT dalam dunia pendidikan juga perlu ditingkatkan.

3. Ketiga, guru adalah ujung tombak dari keberhasilan pendidikan. Untuk itu, masalah yang terkait dengan guru harus segera diatasi. Problem pemerataan guru harus segera dilakukan. Saat ini, masih terjadi kekurangan guru di sekolah-sekolah terpencil, sementara di perkotaan kelebihan guru sehingga malah kekurangan jam mengajar. Pengetahuan dan keterampilan guru juga perlu ditingkatkan melalui pelatihan secara berkala (Nanang, 2014).

\section{Perlu dukungan Organisasi Pembelajar}

Untuk memperbaiki mutu keluaran LPI diperlukan organisasi pembelajar. Organisasi yang digambarkan sebagai sistem pembelajaran bukanlah hal baru. Pada pengertian abad, pendapat Frederick W. Taylor mengenai manajemen ilmiah dapat ditransfer pada pekerja agar organisasi lebih efisien. Akan tetapi, penggunaan istilah organisasi pembelajaran biasanya dihubungkan dengan karya Chris Argyris dan rekan kerjanya yang membuat perbedaan antara pembelajaran urutan pertama, atau "single-loop," dan urutan kedua adalah "doubleloop". perbedaan antara dua jenis pembelajaran yang diterapkan pada organisasi dapat diringkas sebagai berikut:

1. Pembelajaran single-loop mencakup pengembangan kapasitas organisasi untuk mencapai tujuan yang diketahui. Hal tersebut berhubungan dengan pembelajaran rutin dan berhubungan dengan perilaku. Dalam single-loop, organisasi melewati proses pembelajaran tanpa perubahan signifikan.

2. Pembelajaran double-loop mengevaluasi kembali sifat tujuan organisasi dan nilai serta kepercayaan di sekitarnya. Jenis pembelajaran ini mencakup perubahan budaya organisasi. Double-loop mencakup pembelajaran mengenai bagaimana memelajari 
organisasi (Fred Luthans, 2006).

Organisasi pembelajaran juga ditandai dengan nilai budaya yang berorientasi pada manusia seperti berikut ini: (1) setiap manusia dapat menjadi sumber ide yang berguna, personalia harus member akses informasi sehingga menjadi nilai berharga untuk mereka; (2) manusia yang dekat dengan sumber masalah biasanya punya ide pemecahan masalah terbaik, jadi pemberian wewenang sebaiknya dilakukan melalui struktur; (3) aliran pembelajaran naik dan turun, jadi manajer dan karyawan dapat diuntungkan; (4) ide baru adalah penting, sebaiknya didorong dan dihargai; dan (5) kesalahan sebaiknya dilihat sebagai kesempatan belajar. Belajar dari kesalahan merupakan nilai budaya yang penting bagi manusia dalam organisasi pembelajan.

\section{a. Langkah-langkah Yang Harus Dilakukan}

Beberapa langkah praktis yang perlu dilakukan top management untuk membangun kembali budaya organisasinya. Pertama, rombaklah gaya kepemimpinan Anda yang otoriter, kaku dan tertutup terhadap karyawan, dengan gaya kepemimpinan yang terbuka dan transformatif. Gaya kepemimpinan yang terbuka artinya adanya transparansi dan akuntabilitas dari pimpinan untuk memberikan pertanggungjawaban atau penjelasan secara terbuka dan jujur kepada parakaryawan tentang segala hal yang berkaitan dengan apa saja yang telah, sedang dan akan dilaksanakan atau dicapai oleh organisasi. Gaya kepemimpinan yang transformatif (transformational leadership) artinya kepemimpinan yang memiliki visi ke depan dan mampu mengidentifikasi perubahan lingkungan serta mampu mentransformasikan perubahan tersebut ke dalam organisasi; mempelopori perubahan dan memberikan motivasi dan inspirasi kepada individuindividu karyawan untuk kreatif dan inovatif, serta membangun teamwork yang solid; membawa pembaharuan dalam etos kerja dan kinerja manajemen; berani dan bertanggung jawab memimpin dan mengendalikan organisasi (Lako 1996). Dengan gaya kepemimpinan seperti ini, para karyawan akan "jatuh hati” dan mendukung keinginan Anda untuk mendesain kembali budaya organisasi.

Kedua, ajaklah para manajer dan karyawan untuk mendialogkan secara terbuka dan jujur mengenai segala hal, baik yang menyangkut masalah-masalah karyawan, manajemen dan organisasi, maupun harapan-harapan Anda dan harapan-harapan 


\section{Mahmudi}

manajer dan karyawan untuk membangun kesuksesan organisasi yang berkelanjutan. Ketiga, sampaikan kepada para karyawan niat tulus Anda untuk melakukan "reformasi" budaya organisasi dan ajaklah mereka untuk terlibat aktif dalam proses reformasi tersebut. Dalam proses ini, ubahlah paradigma lama pandangan Anda terhadap karyawan. Perlakukan para karyawan bukan sebagai aset organisasi yang apabila sudah tidak berguna akan "dibuang", tetapi sebagai anggota organisasi (stakeholder) yang ikut memiliki perusahaan.

Keempat, berilah pelatihan, pengembangan dan sosialisasi yang memadai kepada para manajer dan karyawan agar mereka dapat memahami dan mengimplementasikan visi, misi, tujuan dan sasaran dari budaya perusahaan yang baru dibangun. Kelima, desainlah kembali sistem manajemen dan sistem pengendalian organisasi yang esuai dengan jiwa dan semangat baru budaya organisasi yang baru dibangun. Keenam,bila terasa sulit, mintalah jasa konsultan yang profesional dan kompeten untuk membantu Anda dalam membangun atau mendesain kembali suatu model budaya organisasi yang kuat, dinamis dan adaptif yang cocok dengan bentuk, karakteristik, mission statement, tujuan dan sasaran organisasi anda (A Usmara dan Lukas Dwiantara, 2006).

\section{b. Perubahan Yang Harus Dikelola}

Menurut ukurannya, perubahan dapat dibagi menjadi dua macam:

(1) perubahan kecil, dan (2) perubahan besar. Perubahan kecil dilaksanakan secara bertahap atau secara perlahan-lahan, dengan langkah-langkah perubahan kecil, sedangkan perubahan besar adalah perubahan yang bersifat transformasional. Perubahan Kecil (Incremental Change). Perubahan kecil biasanya merupakan hasil suatu analisis rasional dan proses perencanaan. Perubahan ini merupakan suatu tujuan yang diinginkan dengan serangkaian langkah khusus untuk mewujudkannya. Perubahan kecil umumnya terbatas lingkupnya dan seringkali dapat dikembalikan ke asal perubahan. Jika perubahan tidak berhasil, kita dapat selalu kembali ke cara lama. Perubahan kecil biasanya tidak mengganggu pola lama-perubahan ini merupkan kepanjangan dari apa yang telah dilakukan di masa lalu. Dalam proses perubahan kecil ini, kita merasakan bahwa kita masih dalam posisi mengendalikan. 
Perubahan Transformasional (Transformational Change). Perubahan transformasional merupakan perubahan mendalam yang menuntut cara baru untuk berpikir dan berperilaku. Perubahan ini mempunyai lingkup luas, tidak berhubungan dengan masa lalu, dan umumnya tidak dapat dikembalikan ke kondisi asal perubahan. Perubahan transformasional mengubah secara mendasar pola tindakan kita, dan mencakup pengambilan risiko. Dalam proses perubahan transformasional, kita melepaskan diri dari posisi pengendalian, karena kita memfokuskan ke eksperimen, yang mempunyai kemungkinan gagal.

\section{c. Siklus Transformasional}

Setelah manajer menyadari karakteristik perubahan yang terjadi dalam lingkungan bisnis global, dan setelah peran manajer dirumuskan kembali sehingga di dalamnya terkandung tanggung jawab untuk melaksanakan improvement secara berkelanjutan, timbul kebutuhan sekarang untuk memperoleh kompetensi dalam bidang pengelolaan perubahan. Untuk memenuhi kebutuhan itu, berikut ini diuraikan tahap- tahap perubahan transformasional dan kompetensi yang dituntut dari manajer untuk mengelolanya. Siklus perubahan transformasional dimulai dengan timbulnya keinginan untuk berubah. Pada saat keinginan untuk berubah ini timbul, faktor yang dapat membelokkan arah perubahan adalah ketakutan terhadap kegagalan. Ketakutan untuk gagal menyebabkan organisasi memasuki jebakan pertama: stagnasi. Jika keinginan untuk berubah tidak terhalang oleh ketakutan terhadap kegagalan, proses perubahan kemuduan akan menuju ke perumusan dan pengkomunikasian visi perubahan. Visi perubahan yang tidak diwujudkan ke dalam tindakan perubahan akan membawa organisasi memasuki jebakankedua:ilusi(A UsmaradanLukas Dwiantara, 2006).

Visi perubahan yang kemudian diwujudkan ke dalam langkah percobaan untuk mewujudkan visi tersebut akan menggerakkan lebih lanjut proses perubahan transformasional. Namun, jika organisasi menghadapi kegagalan dalam proses percobaan tersebut, organisasi dapat memasuki jebakan ketiga: panik. Jika organisasi mampu mencapai keberhasilan dalam proses percobaan, personel organisasi akan memperoleh wawasan baru tentang perubahan yang berhasil dicapai. Keberhasilan berbagai percobaan yang dilakukan akan menegaskan (confirm) kebenaran jalan yang 
ditempuh dalam proses perubahan.

\section{Dukungan Kepemimpinan Profetik}

\section{a. Kepemimpinan Profetik}

Yang dimaksud dengan Kepemimpinan Profetik adalah kemampuan seseorang untuk mempengaruhi orang lain mencapai tujuan sebagaimana para nabi dan rosul/prophet melakukannya (Adz-Dzakiey, 2005). Istilah profetik di Indonesia diperkenalkan oleh Kuntowijoyo (1991) melalui gagasannya mengenai pentingnya ilmu sosial transformatif yang disebut ilmu sosial profetik. Ilmu sosial profetik tidak hanya menjelaskan dan mengubah fenomena sosial, tapi juga memberi petunjuk ke arah mana transformasi dilakukan, untuk apa, dan oleh siapa. Ilmu sosial profetik mengusulkan perubahan berdasarkan citacita etik dan profetik tertentu (dalam hal ini etika Islam), yang melakukan reorientasi terhadap epistemologi, yaitu reoreintasi terhadap mode of thought dan mode of inquiry bahwa sumber ilmu pengetahuan tidak hanya dari rasio dan empiri, tetapi juga dari wahyu.

Berdasarkan pengertian tersebut, kepemimpinan profetik dalam penelitian ini merupakan konsep kepemimpinan yang disusun berdasarkan sudut pandang agama, dalam hal ini Agama Islam, yang diimplementasikan dalam kehidupan masyarakat muslim Indonesia. Apabila diletakkan dalam konteks teori kepemimpinan yang telah dijelaskan di muka, kajian kepemimpinan profetik termasuk dalam kajian kepemimpinan moral dan kepemimpinan lintas budaya. Kepemimpinan profetik juga telah dikaji secara konseptual berdasarkan pendekatan iman Kristiani namun konstruk teoritis dan pengukurannya belum disusun.Hasil penelitian tahap pertama adalah makna kepemimpinan profetik yaitu sistem / aktivitas memanage, mengarahkan, membimbing, sehingga mau dibimbing secara tulus, ikhlas sebagaimana dilaksanakan oleh nabi dan rosul. Kepemimpinan profetik juga mempunyai makna aktivitas mempengaruhi orang lain dengan tulus, didukung kekuatan rabbani dan wahyu, artinya terjadi pencerahan jiwa, dan pembersihan ruhani, diisi cahaya ke-Tuhanan. Dimensi kepemimpinan profetik terdiri dari empat aspek, yaitu sidiq, amanah, tabligh, dan fathonah (Sus Budiharto, 2006). 


\section{b. Kepemimpinan Transformatif}

Kepemimpinan transasksional adalah kepemimpinan yang lebih menekankan pada trasaksi interpersonal antara pemimpin dan karyawan yang melibatkan hubungan pertukaran (exchange). Karyawan memperoleh imbalan segera (immediate) dan nyata (tangible) apabila memenuhi perintah pemimpin (Locke et. al., 1991). Menurut Burns (1978), pemimpin transaksional memotivasi bawahannya melalui pemberian imbalan kontijen (contingent reward) dan manajemen melalui eksepsi (management by exception).

Pemimpin transformasional adalah seseorang yang memiliki charisma yang mampu melakukan stimulasi intelektual para bawahannya sehingga bawahan mampu menggunakan cara baru dalam menghadapi masalah-masalah organisasi. Karakteristik kepemimpinan transfor- masional ditunjukkan melalui empat faktor perilaku: inspirational motivation, individual consideration, intellectual stimulation, serta idealized influence (Bass, 1985: 1990 ).

Beberapa tahun yang lalu James Mac Gregor Burns mengidentifikasi dua jenis kepemimpinan politis: transaksional dan transformasional. Kepemimpinan transaksional tradisional mencakup hubungan pertukaran antara pemimpin dan pengikut, tetapi kepemimpinan transformasional lebih mendasarkan pada pergeseran nilai dan kepercayaan pemimpin, serta kebutuhan pengikutnya. Berdasarkan penemuan penelitiannya, Bass menyimpulkan bahwa banyak contoh (seperti mengandalkan manajemen pasif) yang menunjukkan bahwa kepemimpinan transaksional adalah resep dari keadaan seimbang dan bahwa kepemimpinan transformasional membawa keadaan menuju kinerja tinggi pada organisasi yang menghadapi tuntutan pembaruan dan perubahan. Dia menyatakan bahwa dengan membantu kepemimpinan transformasional melalui kebijakan rekruitmen, seleksi, promosi, pelatihan, dan pengembangan akan menghasilkan kesehatan, kebahagiaan (well being) dan kinerja efektif pada organisasi masa kini (Fred Luthans, 2006).

Dengan demikian dibutuhkan kepemimpinan yang bersifat transformatif, yaitu kepemimpinan yang mampu mengembangkan gerakan inovatif, mampu memberdayakan staf dan organisasi ke dalam suatu perubahan cara berpikir, 


\section{Mahmudi}

pengembangan visi, pengertian dan pemahaman tentang tujuan organisasi serta membawa keperubahan yang tidak henti hentinya atau terus menerus dengan pengolahan aktivitas kerja dengan memanfaatkan bakat, keahlian, kemampuan ide dan pengalaman sehingga setiap pegawai merasa terlibat dan bertanggung jawab dalam menyelesaikan pekerjaan (Mujiasih dan Sutrisno Hadi, 2003). Gaya kepemimpinan yang ditampilkan seorang pemimpin yang bersifat transformatif diharapkan dapat meningkatkan motivasi bawahan untuk mencapai hasil kerja yang optimal. Oleh karena itu dibutuhkan gaya kepemimpinan transformasional yang merupakan gaya kepemimpinan yang mulai diperhitungkan kegunaannya dalam menghadapi perubahan, baik perubahan internal maupun eksternal, demikian juga untuk menumbuhkan motivasi bawahan dalam rangka meningkatkan kinerjanya (Wagimo, 2005).

\section{SIMPULAN DAN SARAN}

Peluang sekaligus tantangan globalisasi menuntut adanya SDM unggul dan kompetetif serta startegi yang perlu direspon secara positif oleh pendidikan Islam. Peluang tersebut perlu disambut dengan memanfaatkan seluruh potensi positif globalisasi, yaitu menyebarkan nilainilai Islam ke seluruh dunia sebagai upaya menyelamatkan umat manusia dari virus skularisasi yang mengabaikan dimensi rohaniah dalam diri manusia. Selainitu, pendidikan Islam perlu mengembangkan pendidikan berbasis spiritual yang didukung oleh guru penuh semangat, organisasi pendidikan pembelajar dan dukungan penuh kepemimpinan profetik transformasional.

\section{DAFTAR PUSTAKA}

Abdurrahman An-Nahlawi, Prinsip-Prinsip dan Metode Pendidikan Islam, Terjemahan Herri Nur Ali, Diponegoro Bandung, 1989

Avin Fadilla Helmi dan MadaIman Arisudana, Kepemimpinan Transformasional, Kepercayaan dan Berbagi Pengetahuan dalam Organisasi, JURNAL PSIKOLOGI. VOLUME 36, NO. 2, DESEMBER 2009

AUsmara dan Lukas Dwiantara (editor), Strategi Organisasi, Yogyakarta: penerbit asmara books, 2006

Bachtiar Alam, Globalisasi dan Perubahan Budaya: Perspektif Teori Kebudayaan, makalah dipresentasikan padaWidyakarya Nasional "Antropologi dan Pembangunan" di 
Jakarta, 26-28 Agustus 1997,

Budi Santoro (Komisioner Ombudsman RI), Benahi Tujuh Masalah Pendidikan, jumat 12 Desember 2014.

Fasli Jalal dan Dedi Supriadi (editor), Reformasi Pendidikan Dalam Konteks Otonomi Daerah, Yogyakarta: Adicita Karya Nosa, 2001

Fred Luthans, Perilaku Organisasi, Yogyakarta: Penerbit Andi, 2006 Firdaus Basuni, Membangun Pendidikan Madrasah Yang Kompetitif DiEra Globalisasi, dalam jurnal Analisis, Volume XIII, Nomor 2,Desember 2013.

Hadi Soesanto, Kebijakan Persaingan, Daya Saing, Liberalisasi, Globalisasi, Regionalisasi dan Seтua Itu, Jakarta: CSIS Working Paper Series, 2004

Iskadar Wiryokusumu dan Usman Mulyadi,Dasar Dasar Pengembangan Kurikulum, Jakarta: PT Bintang Aksara, 1988.

Miftahun Ni'mah Suseno dan Sugiyanto, Pengaruh Dukungan Sosial dan

Kepemimpinan Transformasional Terhadap Komitmen Organisasi dengan Mediator Motivasi Kerja, JURNAL PSIKOLOGI, VOLUME 37, NO. 1, JUNI 2010: $94-109$

Mohammad Ali, Pendidikan Untuk Pembangunan Nasional, Menuju Bangsa Indonesia Yang Mandiri dan Berdaya Saing Tinggi, Jakarta: PT Imperial Bhakti Utama, 2009 Nanang Suprayogi, Pendekatan Holistik Pendidikan, dalam Republika, jumat 12 Desember 2014, hal. 6 .

RencanaStrategis Departemen Pendidikan Nasional Tahun 2005-2009Menuju Pembangunan Pendidikan Nasional Jangka Panjang 2025, Jakarta: Depdikbut, 2005.

Sus Budiharto dan Fathul Himam, Konstruk Teoritis dan Pengukuran Kepemimpinan Profetik, Jurnal Psikologi Fakultas Psikologi Universitas Gadjah Mada Volume 33, No. 2, 133 - 146, 2006.

Wagimo dan Djamaludin Ancok, Hubungan Kepemimpinan Transformasional danTransaksional dengan Motivasi Bawahan di Militer, Jurnal Psikologi. Volume 32, No. 2, 112-127, 2005. 